\title{
Thermal Expansion and Glass Transition Temperatures of Y-Mg-Si-Al-O-N Glasses
}

\author{
Irene M. Peterson ${ }^{*}$ and Tseng-Ying Tien
}

Department of Materials Science and Engineering, The University of Michigan, Ann Arbor, Michigan 48109

\begin{abstract}
The thermal expansion coefficients and glass transition temperatures of $\mathrm{Y}-\mathrm{Mg}-\mathrm{Si}-\mathrm{Al}-\mathrm{O}-\mathrm{N}$ glasses were measured using dilatometry. The thermal expansion coefficients of these glasses could be calculated on the basis of composition, using experimentally determined thermal expansion prefactors.
\end{abstract}

\section{Introduction}

$\mathrm{T}$ HERMAL expansion coefficients and glass transition temperatures have been reported for several $\mathrm{Mg}-\mathrm{Si}-\mathrm{Al}-\mathrm{O}-\mathrm{N}^{l}$ and $\mathrm{Y}-\mathrm{Si}-\mathrm{Al}-\mathrm{O}-\mathrm{N}^{2}$ glasses. However, these have not resulted in simple equations to describe the properties of the glass as a function of chemical composition. This makes design of a glass with given properties difficult. To develop descriptive equations, glass-forming compositions in the system $\mathrm{Y}, \mathrm{Si}, \mathrm{Al}, \mathrm{Mg} / \mathrm{N}, \mathrm{O}$ were selected for this study. Oxynitride glasses in the $\mathrm{Y}, \mathrm{Si}, \mathrm{Al}$, $\mathrm{Mg} / \mathrm{N}, \mathrm{O}$ system are found at the grain boundaries in many silicon nitride ceramics. Therefore, the properties of glasses in these systems are of interest because of their influence on the mechanical properties of silicon nitride ceramics.

The glass transition temperature and Young's modulus depend on the coordination number of elements in the glass and the strength of attraction between elements in the glass. Cations which have high coordination numbers and nondirectional bonds raise the glass transition temperature. ${ }^{3}$ For example, IR investigations ${ }^{4}$ on oxynitride glasses showed that $\mathrm{Mg}^{2+}$ participates in the formative network, while $\mathrm{Ca}^{2+}$ is a network modifier. Drew et al. ${ }^{5}$ found that oxynitride glasses which contained $\mathrm{Ca}^{2+}$ (in 6-fold coordination) had higher glass transition temperatures than those which contained $\mathrm{Mg}^{2+}$ (in 4-fold coordination)

When different cations which have the same coordination number are used, the glass transition temperature increases as the ionic field strength of the cation increases. For example, replacement of $\mathrm{Nd}^{3+}$ by the smaller $\mathrm{Y}^{3+}$ raises the glass transition temperature. ${ }^{5}$ Drew et al. replaced $\mathrm{Mg}^{2+}$ by $\mathrm{Y}^{3+}$, which has both a higher field strength and higher coordination number than $\mathrm{Mg}^{2+}$, and found that the glass transition temperature of the glass increased, as expected.

The glass transition temperature is also affected by the structure of the glass. Mulfinger ${ }^{6}$ suggested that the presence of nitrogen would change the structure of the glass, because each nitrogen was able to bond to three silicon atoms, while oxygen could bond to only two silicon atoms. As a result, the number of bonds between $\operatorname{Si}(\mathrm{O}, \mathrm{N})_{x}$ tetrahedra in the network would increase. Measurement by X-ray photoelectron spectroscopy, raman spectroscopy, and $29 \mathrm{Si}$ NMR spectroscopy indicate that

\footnotetext{
S. Hampshire-contributing editor
}

Manuscript No. 193035. Received November 21, 1994; approved April 10, 1995.

Presented at the 95th Annual Meeting of the American Ceramic Society. Cincinnati, OH, April 20, 1993 (Structure, Morphology, and Properties of Surfaces and Interfaces Symposium, Paper No. SXVI-18-93).

Supported by Oak Ridge National Laboratory through Contract No. DE-AC05 $840 R 2140$ and the Army Research Office through contract No. DOD-G-DAALO3 92-G-0053.

Member, American Ceramic Society. nitrogen bonds to silicon in the glass network, as Mulfinger suggested. ${ }^{7-9}$ NMR spectroscopy has revealed evidence of some $\mathrm{Al}-\mathrm{N}$ bonding, although it is not as prevalent as $\mathrm{Si}-\mathrm{N}$ bonding. ${ }^{10,11}$

An increase in the number of bonds between tetrahedral structural units would be expected to increase the density of the glass. Homeny and McGarry ${ }^{12}$ measured a linear increase in density with increasing nitrogen content in $\mathrm{Mg}-\mathrm{Si}-\mathrm{Al}-\mathrm{O}-\mathrm{N}$ glasses.

Since the substitution of nitrogen for oxygen increases the coordination number of the anion in the glass structure, the glass transition temperature would be expected to increase as the nitrogen content of the glass increased. Large increases in the glass transition temperature have been observed as the amount of nitrogen increases in many compositions, including Mg-Si-Al-O-N, Ca-Si-Al-O-N, Y-Al-Si-O-N, Nd-Si-Al-O-N and $\mathrm{Ba}-\mathrm{Al}-\mathrm{Si}-\mathrm{O}-\mathrm{N}$ compositions. ${ }^{5,13-17}$ When the cation ratios in the glass are held constant, the $T_{\mathrm{g}}$ increases linearly with the atomic percent nitrogen in the glass. ${ }^{5.16}$

The thermal expansion coefficient of the glass depends on the asymmetry of the amplitude of thermal vibrations in the glass. The amplitudes of the thermal vibrations are small when there are many strong bonds present in the network. As a result, the thermal expansion coefficient decreases as the rigidity of the glass network increases.

Modifying cations decrease the rigidity of the glass network by introducing nonbridging oxygen ions, and therefore increase the thermal expansion coefficient of the glass. Other changes in the structure or chemistry of the glass also change the thermal expansion coefficient of the glass. The change in the thermal expansion coefficient of the glass which is caused by different additives is often directly proportional to the amount of additive. If the change in the thermal expansion coefficient of the glass, $\Delta \alpha$, caused by the additive is divided by the amount of additive, $x$, the result is the thermal expansion prefactor for that additive, $\alpha_{i}$.

The thermal expansion coefficient of the glass can be calculated from the weighted sum of the thermal expansion prefactors of the constituents of the glass, as expressed in Eq. (1):

$$
\alpha=\sum \alpha_{\mathrm{i}} X_{\mathrm{i}}
$$

where $X_{\mathrm{i}}$ is the mole fraction of the constituent and $\alpha_{i}$ is the empirically determined thermal expansion coefficient prefactor. ${ }^{17}$

Takahashi ${ }^{18}$ had determined the thermal expansion coefficient prefactors for $\mathrm{Al}_{2} \mathrm{O}_{3}$ and $\mathrm{MgO}$. Appen ${ }^{19}$ had determined the prefactors for $\mathrm{MgO}$ and $\mathrm{SiO}_{2}$. Using their prefactors, the unknown prefactors for $\mathrm{Y}_{2} \mathrm{O}_{3}$ and $\mathrm{Si}_{3} \mathrm{~N}_{4}$ were determined.

\section{Experimental Procedures}

The glasses were synthesized from the starting powders, $\mathrm{Al}_{2} \mathrm{O}_{3}, \mathrm{Si}_{3} \mathrm{~N}_{4}, \mathrm{SiO}_{2}, \mathrm{Y}_{2} \mathrm{O}_{3}$, and $\mathrm{MgO}$. The compositions prepared are listed in Table I. The powders were mixed by hand with isopropyl alcohol with an agate mortar and pestle, dried, and cold pressed into pellets. The pellets were melted at $1650^{\circ} \mathrm{C}$ for $2 \mathrm{~h}$ under $10 \mathrm{~atm}$ of nitrogen. The samples were quenched by turning off the power to the furnace and cooled to room temperature in approximately $3 \mathrm{~h}$. The presence of crystalline 
Table I. Glass Compositions (in Moles)

\begin{tabular}{llllll}
\hline $\mathrm{SiO}_{2}$ & $\mathrm{Al}_{2} \mathrm{O}_{3}$ & $\mathrm{Y}_{2} \mathrm{O}_{3}$ & $\mathrm{MgO}$ & $\mathrm{Si}_{3} \mathrm{~N}_{4}$ & $\alpha_{\text {Measured }} \times 10^{6} \mathrm{PC}$ \\
\hline 0.55 & 0.22 & 0 & 0.22 & 0 & 4.0 \\
0.54 & 0.22 & 0 & 0.21 & 0.02 & 3.7 \\
0.53 & 0.21 & 0 & 0.21 & 0.05 & 3.6 \\
0.53 & 0.22 & 0 & 0.22 & 0.02 & 4.2 \\
0.50 & 0.22 & 0 & 0.22 & 0.04 & 4.0 \\
0.47 & 0.22 & 0 & 0.23 & 0.06 & 3.1 \\
0.52 & 0.24 & 0.01 & 0.21 & 0 & 4.1 \\
0.52 & 0.23 & 0.01 & 0.20 & 0.02 & 4.5 \\
0.49 & 0.22 & 0.01 & 0.20 & 0.05 & 4.0 \\
0.51 & 0.25 & 0.02 & 0.20 & 0 & 4.1 \\
0.50 & 0.26 & 0.03 & 0.19 & 0 & 4.3 \\
0.48 & 0.27 & 0.05 & 0.19 & 0 & 4.6 \\
0.46 & 0.28 & 0.06 & 0.19 & 0 & 5.1 \\
0.44 & 0.29 & 0.07 & 0.18 & 0 & 5.2 \\
0.42 & 0.31 & 0.08 & 0.17 & 0 & 5.3 \\
0.38 & 0.34 & 0.11 & 0.15 & 0 & 5.3 \\
0.61 & 0 & 0.30 & 0 & 0.08 & 6.3 \\
0.87 & 0 & 0.12 & 0 & 0 & 5.1 \\
0.60 & 0.06 & 0.33 & 0 & 0 & 7.5 \\
\hline
\end{tabular}

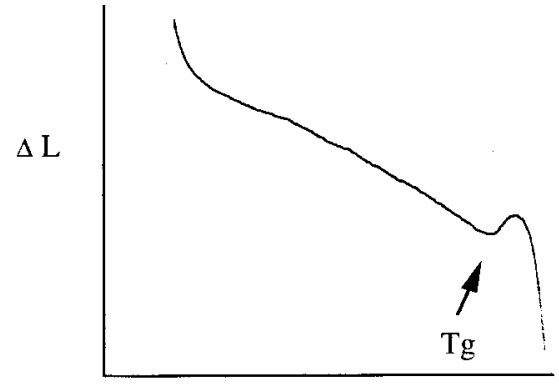

Temperature $\left({ }^{\circ} \mathrm{C}\right)$

Fig. 1. Typical dilatometer trace.

phases was determined by X-ray diffraction. Only samples which did not show any crystalline peaks were used to determine the thermal expansion coefficient and $T_{\mathrm{g}}$ of the glass. The compositions of the glasses were verified using EPMA.

The thermal expansion coefficient was measured from room temperature to $1200^{\circ} \mathrm{C}$, using an alumina single-rod dilatometer calibrated with a fused silica standard. The heating rate was $2^{\circ} \mathrm{C} / \mathrm{min}$. The value of the thermal expansion coefficient from room temperature to $515^{\circ} \mathrm{C}$ was calculated. The $T_{\mathrm{g}}$ was determined from the dilatometer trace. A typical dilatometer trace is shown in Fig. 1, with the $T_{\mathrm{g}}$ indicated.

The thermal expansion coefficient prefactor for $\mathrm{Y}_{2} \mathrm{O}_{3}$ was determined from glasses which contained $\mathrm{MgO}, \mathrm{Al}_{2} \mathrm{O}_{3}, \mathrm{SiO}_{2}$, and $\mathrm{Y}_{2} \mathrm{O}_{3}$ only. The amount of the thermal expansion which was due to $\mathrm{Y}-\mathrm{O}$ bonds, called $\alpha_{\mathrm{Y}_{2} \mathrm{O}_{3}}$, was determined from Eq. (2) below:

$$
\underline{\alpha}_{\mathrm{Y}_{2} \mathrm{O}_{3}}=\alpha_{\text {Measurcd }}-\left\{\alpha_{\mathrm{MgO}} X_{\mathrm{MgO}}+\alpha_{\mathrm{SiO}_{2}} X_{\mathrm{SiO}_{2}}+\alpha_{\mathrm{Al}_{2} \mathrm{O}_{3}} X_{\mathrm{Al}_{2} \mathrm{O}_{3}}\right\}
$$

where

Table II. Thermal Expansion Prefactors

\begin{tabular}{lrcc}
\hline & $\begin{array}{c}\text { This study } \\
\left(\alpha_{i} \times 10^{6} \%^{\circ} \mathrm{C}\right)\end{array}$ & $\begin{array}{c}\text { Takahashi } \\
\left(\alpha_{i} \times 10^{\circ} /{ }^{\circ} \mathrm{C}\right)\end{array}$ & $\begin{array}{c}\text { Appen } \\
\left(\alpha_{i} \times 10^{\circ}{ }^{19} \mathrm{C}\right)\end{array}$ \\
\hline $\mathrm{SiO}_{2}$ & 3.8 & & 3.8 \\
$\mathrm{Al}_{2} \mathrm{O}_{3}$ & 3.1 & 3.1 & \\
$\mathrm{Y}_{2} \mathrm{O}_{3}$ & 15.7 & & \\
$\mathrm{MgO} \mathrm{Si}_{3} \mathrm{~N}_{4}$ & 6.0 & 6.0 & 6.0 \\
$\mathrm{SrO}$ & -7.5 & & \\
$\mathrm{CaO}$ & & & 16 \\
\hline
\end{tabular}

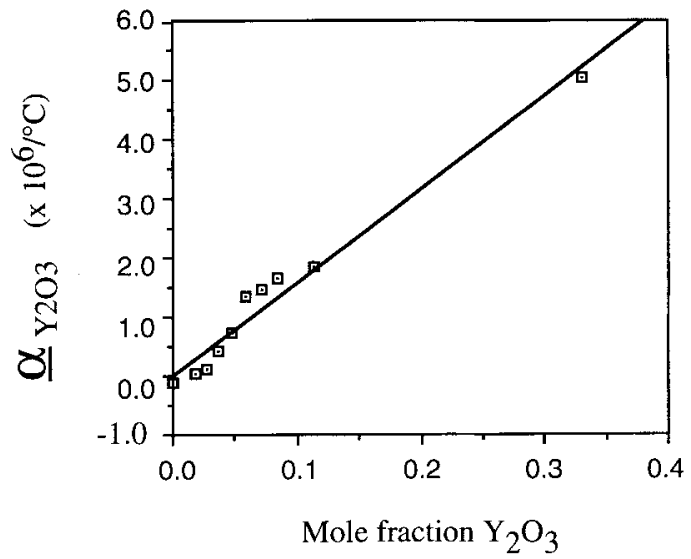

(a)

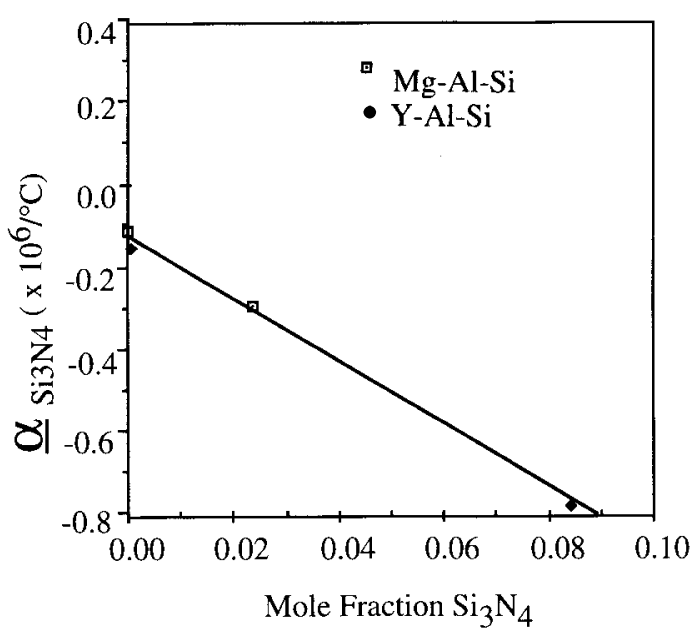

(b)

Fig. 2. (a) Thermal expansion coefficient of the glass increases when $\mathrm{Y}_{2} \mathrm{O}_{3}$ is added. The slope of this plot is the thermal expansion prefactor of $\mathrm{Y}_{2} \mathrm{O}_{3}, \alpha_{Y_{2} \mathrm{O}_{3}}$. (b) The thermal expansion coefficient of the glass decreases when $\mathrm{Si}_{3} \mathrm{~N}_{4}$ is added. The slope of the plot is the thermal expansion prefactor for $\mathrm{Si}_{3} \mathrm{~N}_{4}, \alpha_{\mathrm{Si}_{3} \mathrm{~N}_{4}}$.

$$
\underline{\alpha}_{\mathrm{Y}_{2} \mathrm{O}_{3}}=\alpha_{\mathrm{Y}_{2} \mathrm{O}_{3}} X_{\mathrm{Y}_{2} \mathrm{O}_{3}}
$$

(Equation (2) is an expansion of Eq. (1).) The thermal expansion prefactor of $\mathrm{Si}_{3} \mathrm{~N}_{4}$ was determined using the glass compositions in Table I. The amount of themal expansion which was due to Si-N bonds, called $\alpha_{\mathrm{Si}_{3} \mathrm{~N}_{4}}$, was calculated using Eq. (4): 


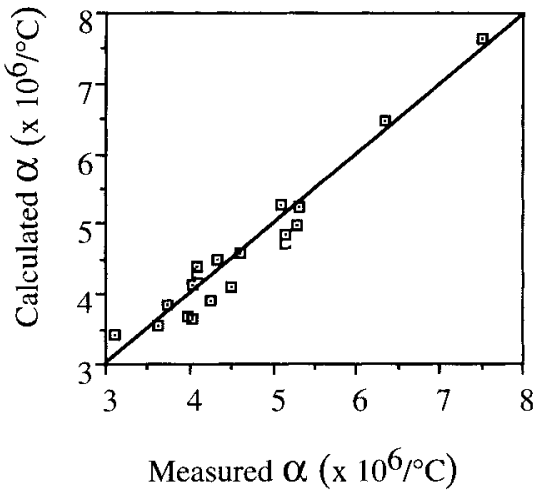

Fig. 3. Comparison of calculated and measured thermal expansion coefficients.

$$
\begin{aligned}
\underline{\alpha}_{\mathrm{Si}_{3} \mathrm{~N}_{4}}= & \alpha_{\text {Measured }}-\left\{\alpha_{\mathrm{MgO}} X_{\mathrm{MgO}}+\alpha_{\mathrm{Al}_{2} \mathrm{O}_{3}} X_{\mathrm{Al}_{2} \mathrm{O}_{3}}\right. \\
& \left.+\alpha_{\mathrm{SiO}_{2}} X_{\mathrm{SiO}_{2}}+\alpha_{\mathrm{Y}_{2} \mathrm{O}_{3}} X_{\mathrm{Y}_{2} \mathrm{O}_{3}}\right\}
\end{aligned}
$$

where

$$
\underline{\alpha}_{\mathrm{Si}_{3} \mathrm{~N}_{4}}=\alpha_{\mathrm{Si}_{3} \mathrm{~N}_{4}} X_{\mathrm{Si}_{3} \mathrm{~N}_{4}}
$$

\section{Results and Discussion}

The thermal expansion coefficients and the glass compositions are listed in Table I. The error in the thermal expansion coefficient measurements is about $2 \times 10^{-7} / \mathrm{C}$, based on the calibration of the dilatometer. The error in temperature measurements is $\pm 2^{\circ} \mathrm{C}$, according to the calibration of the dilatometer thermocouple.

Using previously reported $\alpha_{1}$ values for $\mathrm{MgO}, \mathrm{Al}_{2} \mathrm{O}_{3}$, and $\mathrm{SiO}_{2},{ }^{18,19} \alpha_{\mathrm{i}}$ values for $\mathrm{Si}_{3} \mathrm{~N}_{4}$ and $\mathrm{Y}_{2} \mathrm{O}_{3}$ were determined. The $\alpha_{\mathrm{i}}$ values are listed in Table II. The $\alpha_{1}$ value for $\mathrm{SiO}_{2}$ is valid only when the mole fraction of $\mathrm{SiO}_{2}$ is less than 0.67 . The $\alpha_{i}$ values were determined from plots of $\alpha_{\mathrm{i}}$ as a function of $X_{\mathrm{i}}$. Figure 2(a) shows the plot of $\underline{\alpha}_{\mathrm{Y}_{2} \mathrm{O}_{3}}$ as a function of $X_{\mathrm{Y}_{2} \mathrm{O}_{3}}$. The slope of the plot in Fig. 2 is $\alpha_{Y_{2} \mathrm{O}_{3}}$. Figure 2(b) shows the plot of $\underline{\alpha}_{\mathrm{Si}_{3} \mathrm{~N}_{4}}$ as a function of $X_{\mathrm{Si}_{3} \mathrm{~N}_{4}}$. The slope of the plot in Fig. 2(b) is $\alpha_{\mathrm{Si}_{3} \mathrm{~N}_{4}}$.

Using the $\alpha_{i}$ values listed in Table II, the expected values of the thermal expansion coefficient were calculated. Figure 3 shows the excellent agreement between the calculated and measured values-the maximum error is $10 \%$.

The addition of $\mathrm{Y}_{2} \mathrm{O}_{3}$ and $\mathrm{Al}_{2} \mathrm{O}_{3}$ in a $3: 5$ ratio (YAG) to the original $\mathrm{Mg}$-Si-Al-O-N had little effect on the glass transition temperature of the oxide glass, as shown in Fig. 4.

Figure 5 shows the glass transition temperature as a function of silicon nitride content for $\mathrm{MgO}-\mathrm{Al}_{2} \mathrm{O}_{3}-\mathrm{SiO}_{2}-\mathrm{Si}_{3} \mathrm{~N}_{4}$ and $\mathrm{Y}_{2} \mathrm{O}_{3}-\mathrm{MgO}-\mathrm{Al}_{2} \mathrm{O}_{3}-\mathrm{SiO}_{2}-\mathrm{Si}_{3} \mathrm{~N}_{4}$ glasses. A best-fit line through the data in Fig. 5 results in an empirical equation for the glass

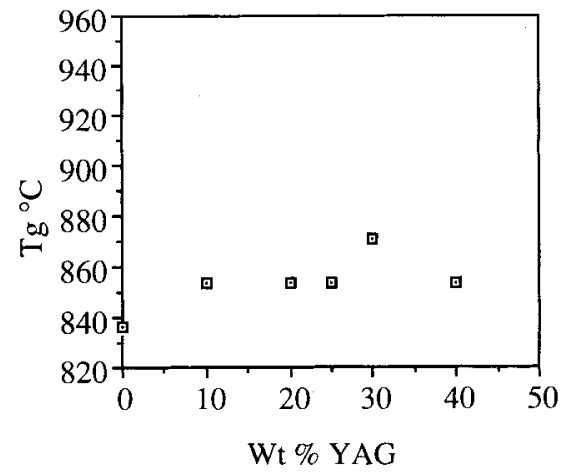

Fig. 4. Small additions of $\mathrm{Y}_{3} \mathrm{Al}_{5} \mathrm{O}_{12}$ to $\mathrm{Mg}-\mathrm{Si}-\mathrm{Al}-\mathrm{O}$ oxide glasses show no effect on $T_{\mathrm{g}}$.

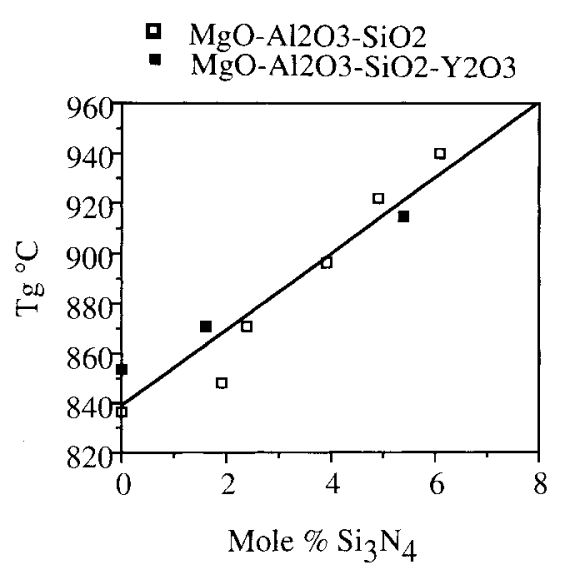

Fig. 5. $\mathrm{Si}_{3} \mathrm{~N}_{4}$ additions raise the $T_{\mathrm{g}}$ of oxynitride glass.

transition temperature. The glass transition temperature can be expressed in Eq. (6):

$$
T_{\mathrm{g}}\left({ }^{\circ} \mathrm{C}\right)=839+15.3\left(\mathrm{~mol}_{0} \mathrm{Si}_{3} \mathrm{~N}_{4}\right)
$$

The thermal expansion coefficients and glass transition temperatures of $\mathrm{Y}-\mathrm{Mg}-\mathrm{Si}-\mathrm{Al}-\mathrm{O}-\mathrm{N}$ glasses can be predicted from simple equations. The thermal expansion prefactors also correspond with the role of the ion in the glass structure. The thermal expansion prefactor of $\mathrm{MgO}$ is much smaller than that of $\mathrm{CaO}$ as expected from both the structural roles and the relative field strengths of the $\mathrm{Mg}^{2+}$ and $\mathrm{Ca}^{2+}$. The high thermal expansion prefactor found for $\mathrm{Y}_{2} \mathrm{O}_{3}$ is consistent with the position of $\mathrm{Y}^{3+}$ as a network modifier but not with its high field strength.

\section{References}

${ }^{1}$ R. E. Loehman, "Oxynitride Glasses," J. Non-Cryst. Solids, 42, 433-46 (1980).

${ }^{2}$ R. E. Loehman, "Preparation and Properties of Yttrium-Silicon-Aluminum Oxynitride Glasses," J. Am. Ceram. Soc., 62 [9-10] 491-94 (1979).

${ }^{3}$ A. Buri, D. Caferra, F. Branda, and A. Marotta, "Relationship between Composition and Glass Transition Temperature in $\mathrm{Na}_{2} \mathrm{O}-\mathrm{M}_{2} \mathrm{O}_{3}-\mathrm{SiO}_{2}$ Glasses (M = Ga, In, Sc,Y, La)," Phys. Chem. Glasses, 23, 37-40 (1982).

${ }^{4} J$. Videau, J. Etourneau, C. Garnier, P. Verdier, and Y. Laurent, "Structural Influence of Nitrogen in Alkaline Earth Aluminosilicate Glasses: IR Absorption Spectroscopy," Mater. Sci. Eng. B, 14, 249-54 (1992).

${ }^{5}$ R. Drew, S. Hampshire, and H. Jack, "Nitrogen Glasses"; pp. 119-32 in Special Ceramics 7, Proceedings of the British Ceramics Society (June 1981). Edited by D. Taylor and P. Popper. British Ceramic Society, Shelton, U.K., 1981.

${ }^{6} \mathrm{H}$. O. Mulfinger, "Physical and Chemical Solubility of Nitrogen in Glass Melts," J. Am. Ceram. Soc., 49, 462 (1966).

J. G. Clabes, R. E. Fern, and G. H. Frischat, "Characterization of Nitrogen Containing Glasses by X-ray Photoelectron Spectroscopy," J. Vac. Sci. Technol. $A, 4$ [3] 1580-84 (1986).

${ }^{8} \mathrm{~T}$. Rouxel, J. Besson, E. Rzepka, and P. Goursat, "Raman Spectra of SiYAlON Glasses and Ceramics," J. Non-Cryst. Solids, 122, 298-304 (1990).

${ }^{9}$ W. Hater, W. Muller-Warmuth, and G. H. Frischat, "29Si MAS NMR Studies of Alkali Silicate Oxynitride," Glastech Ber., 62 [9] 328-64 (1989).

${ }^{10} \mathrm{G}$. Leng-Ward and M. H. Lewis, "Oxynitride Glasses and Their GlassCeramic Derivatives"; pp. 106-53 in Glasses and Glass Ceramics. Edited by C. M. Lewis. Chapman and Hall, London, U.K., 1989.

"R. S. Aujla, G. Leng-Ward, M. H. Lewis, G. F. Seymour, G. A. Styles, and G. W. West, "An NMR Study of Silicon Coordination in Y-Si-Al-O-N Glasses," Philos. Mag. B, 54 [2] L51-L56 (1986).

${ }^{12} \mathrm{~J}$. Homeny and D. McGarry, "Preparation and Mechanical Properties of Mg-Al-Si-O-N Glasses," J. Am. Ceram. Soc., 67 [11] C-225-C-227 (1984).

${ }^{13} \mathrm{D}$. Messier, "Preparation and Properties of Y-Si-Al-O-N Glasses," Int. J. High Tech. Ceram., 3, 33 41 (1987).

${ }^{14} \mathrm{~T}$. Hayashi and T. Y. Tien, "Formation and Crystallization of Oxynitride Glasses in the System Si, Al, Mg/O,N," Yogyo Kyokaishi, 94 [1] 44-62 (1986).

${ }^{15} \mathrm{R}$. Loehman, "Oxynitride Glasses"; pp. 119-48 in Treatise on Materials Science and Technology, Vol. 26, Glass IV. Edited by M. Towozawa and R. Doremus. Academic Press, Orlando, FL, 1985.

${ }^{16}$ W. K. Tredway and S. H. Risbud, "Multianion Glasses"; p. 203 in NonOxide Technical and Engineering Ceramics. Edited by S. Hampshire. Elsevier Applied Science, London, U.K., 1986.

"IJ. M. Stevels, "The Structure and the Physical Properties of Glass"; pp. 511643 in Encyclopedia of Physics, Vol. XIII, Thermodynamics of Liquids and Solids. Edited by S. Flugge. Springer-Verlag, Berlin, Germany, 1962.

${ }^{18} \mathrm{~K}$. Takahashi, "Thermal Expansion Coefficients and the Structure of Glass. Part I," J. Soc. Glass Technol., 37, 3N-7N (1953).

${ }^{19}$ A. A. Appen, Silikattechnik, 3, 113 (1953). 